\title{
Gas exchange, photochemical efficiency, and yield of Jatropha curcas irrigated with saline water
}

\author{
Ivomberg Dourado Magalhães ${ }^{1,8^{*}}$, Alberto Soares de Melo ${ }^{1,9}$, Pedro Dantas Fernandes ${ }^{2,10}$, Messias Firmino \\ de Queiroz ${ }^{3}$, Nair Helena Castro Arriel ${ }^{4}$, Rener Luciano de Souza Ferraz ${ }^{1,3,11}$, Janivan Fernandes Suassuna ${ }^{5}$, \\ Sebastião de Oliveira Maia Júnior ${ }^{6,11}$, Aldair de Souza Medeiros ${ }^{6}$, Pedro Roberto Almeida Viegas ${ }^{7}$, Flavio \\ da Silva Costa ${ }^{5}$, Patricia da Silva Costa ${ }^{2}$
}

\author{
${ }^{1}$ State University of Paraíba, Coordination of the Post-Graduate Program in Agricultural Sciences, Campina Grande, \\ 58429-570, Paraíba, Brazil \\ ${ }^{2}$ Federal University of Campina Grande, Academic Unit of Agricultural Engineering, Campina Grande, 58109-970, \\ Paraíba, Brazil \\ ${ }^{3}$ State University of Paraíba, Center for Agrarian and Environmental Sciences, Lagoa Seca, 58117-000, Paraíba, Brazil \\ ${ }^{4}$ Brazilian Agricultural Research Corporation, Embrapa Algodão, Campina Grande, 58428-095, PB, Brazil \\ ${ }^{5}$ Federal University of Amapá, Field Education Coordination, Mazagão, 68940-000, Amapá, Brazil \\ ${ }^{6}$ Federal University of Alagoas, Department of Plant Production, Maceió, 57072-900, Alagoas, Brazil \\ ${ }^{7}$ Federal University of Sergipe, Department of Agronomic Engineering, São Cristóvão, 49100-000, Sergipe, Brazil \\ ${ }^{8}$ Fellow of CAPES Postdoctoral, PNPD, Brazil \\ ${ }^{9}$ Fellow of CNPq Research Productivity, level 2, Brazil \\ ${ }^{10}$ Fellow of CNPq Research Productivity, level 1C, Brazil \\ ${ }^{11}$ Fellow of CNPq Postdoctoral, PDJ, Brazil
}

*Corresponding author: ivomberg31@hotmail.com

Abstract

Jatropha curcas L. is a rustic plant with great potential for energy source. In semi-arid regions, where water scarcity has been one of the major problems, saline water is an alternative source in agriculture, although it causes losses in crop development and yield. This study was developed to evaluate the photochemical efficiency, gas exchange, and yield of Jatropha curcas irrigated with saline water. The experiment was carried out under five levels $(L)$ of water electrical conductivity: $L_{1}=1.2, L_{2}=1.8, L_{3}=2.4, L_{4}=3.0$, and $L_{5}$ $=3.6 \mathrm{dS} \mathrm{m}^{-1}$, (calibrated at $25 \stackrel{\circ}{\circ}$ ). We conducted physiological assessments such as photochemical efficiency of photosystem II, gas exchange through stomatal conductance, transpiration, $\mathrm{CO}_{2}$ internal concentration and leaf net photosynthesis rate after application of saline water and following prunning. J. curcas production was measured based on the following variables, number of bunches per plant, number of fruits per plant, number of fruits per bunch, weight of shells per plant and weight of seeds per plant. Continuous application of saline water after $J$. curcas pruning caused a drastic reduction of up to $31.1 \%$ in gas exchange $(A, g s, E, C i$, and $\mathrm{A} / \mathrm{Ci}$ ). Photochemical efficiency of photosystem II was restricted by salinity at $2.4 \mathrm{dS} \mathrm{m}^{-1}$ level. Increasing electrical conductivity in irrigation water at levels above $1.20 \mathrm{dS} \mathrm{m}^{-1}$ significantly reduced J. curcas production components by up to $77.3 \%$. Irrigation with saline water up to the level $1.20 \mathrm{dS} \mathrm{m}^{-1}$ did not damage gas exchange and fruit production of Jatropha curcas crop.

Keywords: Fruits production, photosynthesis, physiology, salinity, semi-arid regions.

Abbreviations: $A \_$net photosynthesis; $A / C i$ Instantaneous carboxylation efficiency; $C_{-} \mathrm{CO}_{2}$ internal concentration; $E_{-}$transpiration; ECW_Electrical conductivity levels in the water; EMEPA_Paraíba at the State Agricultural Research Company; Fv/Fm_maximum quantum efficiency of photosystem II; gs_stomatal conductance; NBP_number of bunches per plant; NFB_number of fruits per bunch; NFC_number of fruits per bunches; NFP_number of fruits per plant; NSF_number of seeds per fruit; PSII_photochemical efficiency of photosystem II; WBP_weight of bunch per plant; WSEP_weight of seeds per plant; WSP_weight of shells per plant.

\section{Introduction}

Jatropha curcas L. is a shrub specie belonging to Euphorbiaceae family that can reach $8.0 \mathrm{~m}$ tall under good environmental conditions (Achten et al., 2008; Augustus et al., 2011). J. curcas has a great economic potential because can be used in the pharmaceutical and cosmetic industries.
Currently, there is an increasing interest on Jatropha seeds due to its oil content for biodiesel production (Santos et al., 2013). This specie grows from North to South of Brazil under varied climate and soil conditions (Santana et al., 2017). In semi-arid region of the Northeast of Brazil Jatropha occurs is grown by negative water balance. The annual averages rainfall is less than $800 \mathrm{~mm}$, sunshine of $2,800 \mathrm{~h}_{\text {year }}{ }^{-1}$, and 
annual temperature of $26.5^{\circ} \mathrm{C}$. These conditions induce high evapotranspiration rates that generates water deficit all over the region (Santana et al., 2017), as well as this phenomenon causes salinization of soil and water (Silva et al., 2011; Sousa Júnior et al., 2017).

J. curcas is an interesting option for this region, mostly because it stands out as native specie quite tolerant to water scarcity (Santos et al., 2013; Sapeta et al., 2013; Santana et al., 2017). Despite being tolerant to water deficit, irrigation technique is needed to ensure agricultural production in this region. However, specifically in the semi-arid region, the soil salinity is a limiting factor for crop productivity (Silva et al., 2011; Melo et al., 2017a).

Salinity affects plants through several factors such as inhibition of water absorption, ion balance, and toxicity, as well as it induces several metabolic alterations in the short and long term (Pivetta et al., 2016; Cruz et al., 2017; Melo et al., 2017b; Sousa Júnior et al., 2017). Short-term effects include reduced plant growth, due to osmotic effect of salt, which reduces cell expansion and, long-term effects including ionic stress due to excessive salt absorption which decreases the photosynthetic leaf area available for plant growth (Munns, 2002). In both cases, decline in plant growth is often followed by gas exchange modifications such as low assimilation of photosynthetic $\mathrm{CO}_{2}$ due to stomatal and nonstomatal limitations triggered by the stress (Silva et al., 2011; Cruz et al., 2017; Santana et al., 2017; Sousa Júnior et al., 2017).

Furthermore, salinity negatively influences photosynthetic apparatus of plants, which may be evaluated by chlorophyll $a$ fluorescence (Brito et al., 2016; Melo et al., 2017b). This parameter has been an important tool to assess the photosynthetic performance of plants under saline stress, since the high concentration of salts in irrigation water may causes severe damage to photosynthetic apparatus in most plants (Azevedo Neto et al., 2011; Brito et al., 2016). At this condition, photochemical efficiency of photosystem II (PSII) may be reduced and cause loss of energy by the lightcollecting complex, consequently affecting the biochemical phase of photosynthesis (Brito et al., 2016; Sousa Júnior et al., 2017). Nevertheless, information on the physiological and yield of $J$. curcas in the Brazilian semi-arid region is still scarce, particularly related to the crop physiology and responses to salinity stress.

Therefore, J. curcas has a wide adaptability to diverse environments. We require understanding the mechanism when this plant is submitted to salinity, which may help further cultivations of this plant and obtain higher yields and profitability in view of environmental adversities. Thus, we aimed to evaluate J. curcas gas exchange, photochemical efficiency and production components under different saline water levels.

Results

\section{Physiological variables}

As seen in the analysis of variance (Supplementary Table 1), there was a significant effect of the electrical conductivity levels of the irrigation water for all variables related to gas exchange and the maximum quantum efficiency of photosystem II (Fv/Fm).
Net photosynthesis $(A)$ adjusted to a quadratic model $\left(R^{2}=\right.$ $\left.0.98^{* *}\right)$ and reached a maximum at $3.53 \mu \mathrm{mol}$ de $\mathrm{CO}_{2} \mathrm{~m}^{-2} \mathrm{~s}^{-1}$ at $1.88 \mathrm{dS} \mathrm{m}^{-1}$, afterward it has reduced by $31.1 \%$ until the highest salinity level of $3.6 \mathrm{dS} \mathrm{\textrm {m } ^ { - 1 }}$ (Fig 1A). Likewise, transpiration $(E)$ adjusted to quadratic model $\left(R^{2}=0,93^{*}\right)$ reaching a maximum at $0.9 \mathrm{mmol}$ of $\mathrm{H}_{2} \mathrm{O} \mathrm{m}^{-2} \mathrm{~s}^{-1}$ at $1.8 \mathrm{dS} \mathrm{m}^{-1}$, which corresponded to a $26 \%$ drop up to $3.6 \mathrm{dS} \mathrm{m}^{-1}$ (Fig 1B). Stomatal conductance $(g s)$ it was reduced by $2.5 \%$ from the lowest level of salinity water $\left(1.2 \mathrm{dS} \mathrm{m}^{-1}\right)$ with regard to higher level ( $3.6 \mathrm{dS} \mathrm{m}^{-1}$ ) (Fig 1C), with gs decrease from 0.04 to $0.039 \mathrm{~mol}$ of $\mathrm{H}_{2} \mathrm{O} \mathrm{m}^{-2} \mathrm{~s}^{-1}$, respectively, with adjustment to quadratic model.

Internal carbon concentration it was adjusted to linear regression at salinity levels with a declining by $26 \%$ as the salinity levels of irrigation water increased (Fig 1D). The highest internal $\mathrm{CO}_{2}$ concentration $\left(265 \mu \mathrm{mol} \mathrm{m} \mathrm{m}^{-1}\right)$ was observed at $1.2 \mathrm{dS} \mathrm{m}^{-1}$ initial level of $1.2 \mathrm{dS} \mathrm{m}^{-1}$.

Instantaneous carboxylation efficiency $(A / C i)$ of Jatropha curcas plants was reduced according to salt levels and it has adjusted to a decreasing linear model $\left(R^{2}=0.92^{*}\right)$ and showed a more pronounced loss in the highest level of salinity ( $3.56 \mathrm{dS} \mathrm{m}^{-1}$ ) (Fig 1E).

Increasing salt levels also provided a decline to maximum quantum efficiency of photosystem II since Fv/Fm relation was decreased by $5.4 \%$ between the lower and highest salinity level (Fig 1F).

\section{J. curcas production}

J. curcas fruits production was also negatively affected by salinity. There was negative effect of the water electrical conductivity levels on the number of bunches per plant (NBP) and the number of fruits per plant (NFP) at 65, 95, 125 , and 155 days after the beginning of irrigation with saline water (Supplementary Table 2). The NBP decreased linearly with the increase of the electrical conductivity of the irrigation water throughout the assessed period (Fig 2). At 65 days after application of the irrigation treatments, the highest NBP average (36.58) was reached with the lowest salinity level $1.2 \mathrm{dS} \mathrm{m}^{-1}$, decreasing by $44.20 \%$ as the electrical conductivity of the irrigation water was increased to $3.6 \mathrm{dS} \mathrm{m}^{-1}$ (Fig 2A). At 95 days the reduction reached $72.50 \%$ (Fig 2B). Likewise, at 125 and 155 days the NBP decreased by 50.4 and $77.3 \%$ respectively, between the lowest and highest salinity levels (Figs 2C and 2D).

At 65 days, the number of fruits was reduced with the increasing of saline water, with a decrease of $43 \%$ from the lowest salinity level to the highest one (Fig 3A). At 95, 125, and 155 days the NFP decline 74,27 and $72 \%$, respectively (Figs 3B, 3C, and 3D).

Electrical conductivity levels in the irrigation water it has significant influence on the weight of seeds per plant (WSEP), weight of bunch per plant (WBP), number of seeds per fruit (NSF), and number of fruits per bunch (NFB) (Supplementary Table 3).

The weight of the seeds per plant presented a linear reduction due to the increase of salinity of the water $\left(R^{2}=\right.$ $\left.0.96^{* *}\right)$. The most significant result was observed when plants were irrigated with water $1.2 \mathrm{ds} \mathrm{m}^{-1}$ and it was achieved $84.89 \mathrm{~g}$ in the amount of 187 seeds (Fig 4A). As the electrical conductivity of irrigation water was increased, the 
Table 1. Summary of variance analysis of variables: Jatropha curcas leaf net photosynthesis rate $(A)\left(\mu \mathrm{mol} \mathrm{m}^{-2} \mathrm{~s}^{-1}\right)$, transpiration $(E)$ ( $\mathrm{mmol}$ de $\mathrm{H}_{2} \mathrm{O} \mathrm{m}^{-2} \mathrm{~s}^{-1}$ ), stomatal conductance $(\mathrm{gs})\left(\mathrm{mol} \mathrm{m} \mathrm{m}^{-2} \mathrm{~s}^{-1}\right), \mathrm{CO}_{2}$ internal concentration $(\mathrm{Ci})\left(\mu \mathrm{mol}\right.$ mol ${ }^{-1}$ ), instantaneous carboxylation efficiency $\left.(A / C i)\left[\left(\mu \mathrm{mol} \mathrm{m}^{-2} \mathrm{~s}^{-1}\right)(\mu \mathrm{mol} \mathrm{mol})^{-1}\right)^{-1}\right]$, and maximum quantum efficiency of photosystem II (Fm/Fv) under electrical conductivity levels in the irrigation water. Campina Grande, PB.

\begin{tabular}{|c|c|c|c|c|c|c|c|}
\hline \multirow{3}{*}{ S. V. } & \multirow{3}{*}{ D.F. } & \multicolumn{6}{|c|}{ Mean squares } \\
\hline & & $A$ & $E$ & gs & $\mathrm{Ci}$ & $\mathrm{A} / \mathrm{Ci}$ & $\mathrm{Fm} / \mathrm{Fv}$ \\
\hline & & \multicolumn{6}{|c|}{ 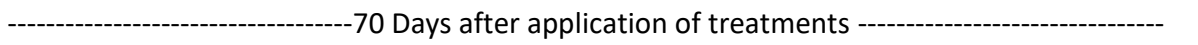 } \\
\hline Block & 2 & $0.0080^{\text {ns }}$ & $0.0253^{\text {ns }}$ & $0.00008^{\mathrm{ns}}$ & $23.40000^{\text {ns }}$ & $256.69^{\text {ns }}$ & $0.00104^{\text {ns }}$ \\
\hline Condutivity & 4 & $2.1558^{* *}$ & $0.3087^{*}$ & $0.00017^{*}$ & $2114.55^{* *}$ & $803.57^{*}$ & $0.00079^{*}$ \\
\hline Square regression & 1 & $5.39291^{*}$ & $0.6168 *$ & $0.00034 *$ & $84.2916^{*}$ & $341.71 *$ & $0.003000^{* *}$ \\
\hline Linear regression & 1 & $3.01467^{*}$ & $0.2632 *$ & $0.00001^{\mathrm{ns}}$ & $4851.40 *$ & $1416.4^{\mathrm{ns}}$ & $0.000038^{\mathrm{ns}}$ \\
\hline Residue & 8 & 0.16259 & 0.0318 & 0.00003 & 12.98 & 330.66 & 0.000105 \\
\hline C.V. (\%) & & 10.92 & 19.96 & 13.36 & 1.57 & 23.7 & 1.42 \\
\hline
\end{tabular}

S.V. - Sources of variation, C.V. - Coefficient of variation; D.F. - Degrees of freedom; ${ }^{* *},{ }^{*}$ - Significant at 1 and $5 \%$ level of significance respectively, ns - non-significant by F test at $5 \%$ level of significance.
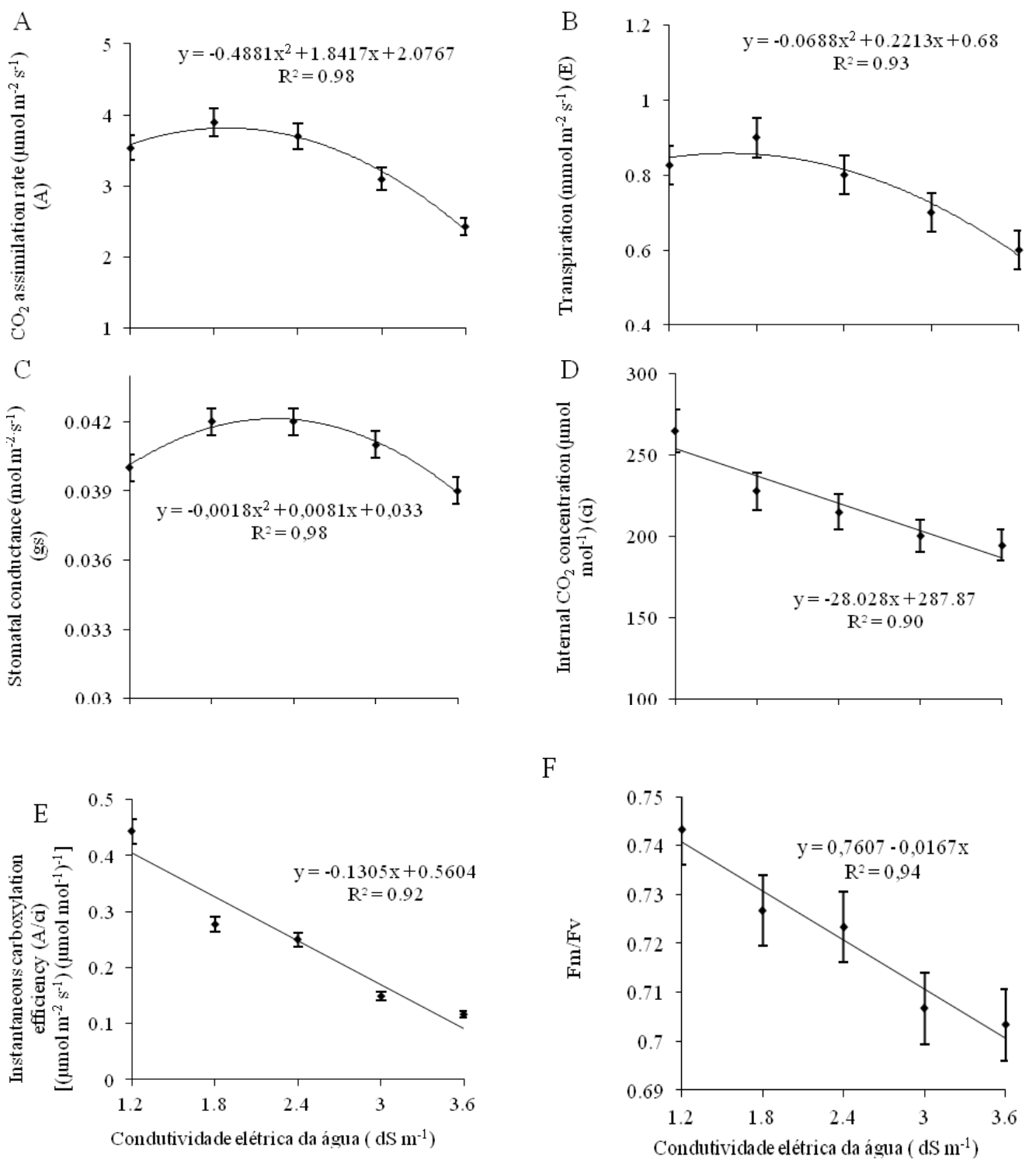

Fig 1. Jatropha curcas $\mathrm{CO}_{2}$ assimilation rate (A), transpiration (B), stomatal conductance (C), internal $\mathrm{CO}_{2}$ concentration (D), instantaneous carboxylation efficiency $(E)$, and maximum quantum efficiency of photosystem II (F) under different electrical conductivity levels in irrigation water. 
Table 2. Summary of variance analysis of number of bunches per plant (NBP) and number of fruits per plants (NFP) at $65,95,125$, and 155 days after treatments application to Jatropha curcas grown under different electrical conductivity levels in irrigation water. Campina Grande, PB.

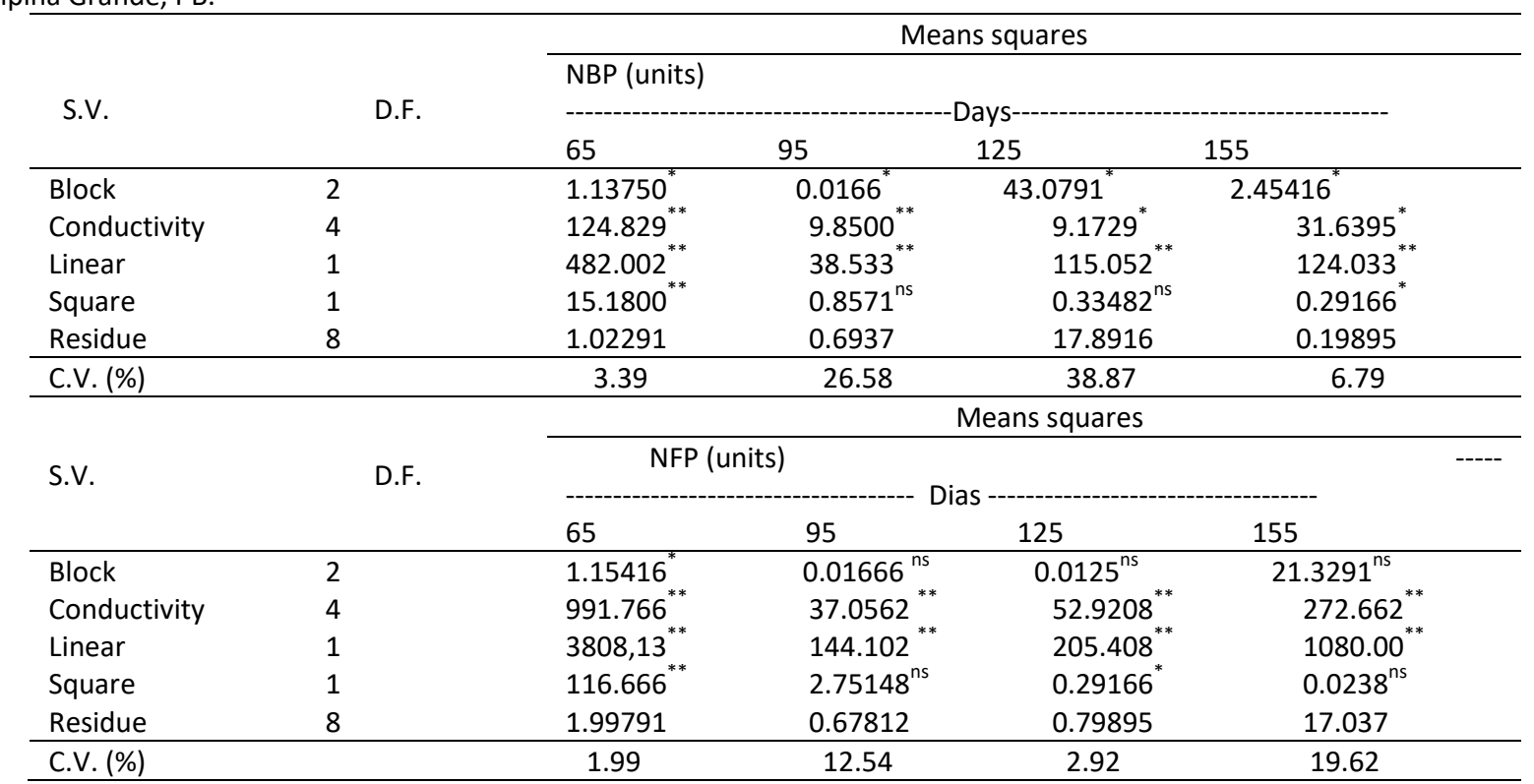

S.V. - Sources of variation, C.V. - Coefficient of variation; D.F. - Degrees of freedom; ${ }^{* *}{ }^{*}{ }^{*}$ - Significant at 1 and $5 \%$ level of significance respectively, ns - non-significant by F test at $5 \%$ level of significance.
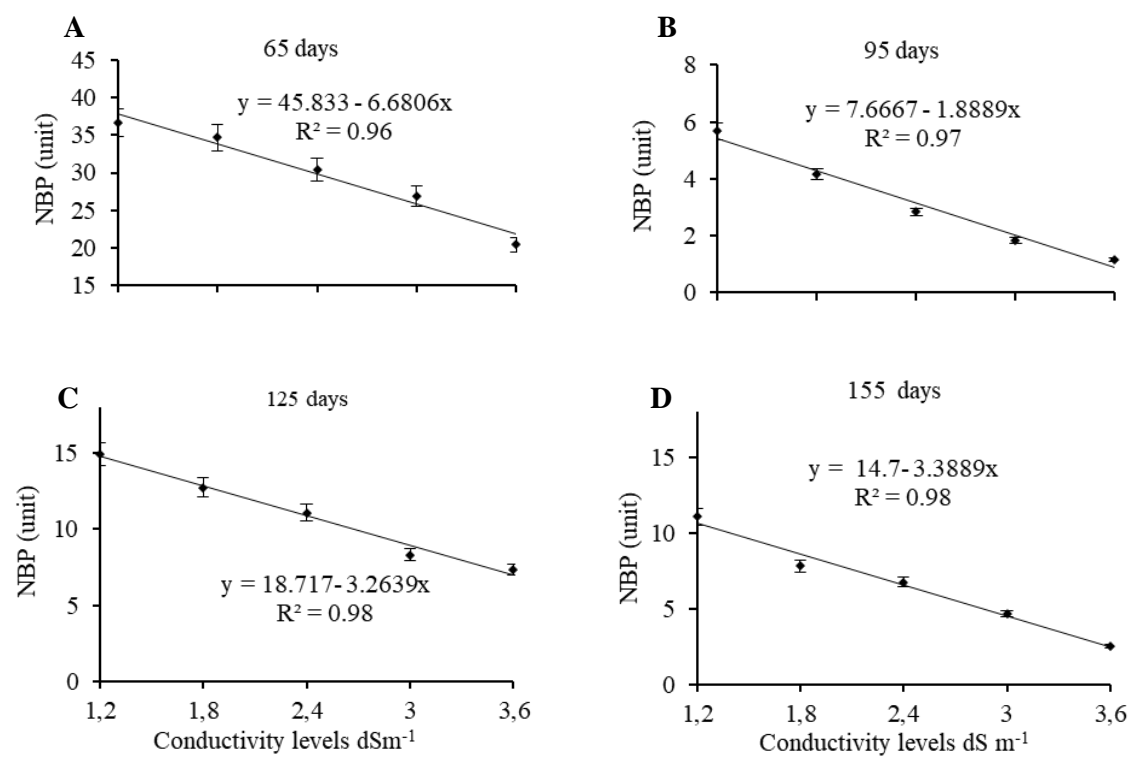

Fig 2. Jatropha curcas number of bunches per plant (NBP) at 65 (A), 95 (B), 125 (C), and 155 (D) days after the beginning of application of different electrical conductivity levels in the irrigation water.

Table 3. Summary of the analysis of variance of weight of seeds per plant (WSP), weight of bunches per plant (WBP), number of seeds per fruit (NSF), and number of fruits per bunch (NFB). Campina Grande, PB.

\begin{tabular}{|c|c|c|c|c|c|}
\hline \multirow[b]{2}{*}{ S.V. } & \multirow[b]{2}{*}{ D.F. } & \multicolumn{4}{|c|}{ Means squares } \\
\hline & & WSP (kg) & WBP (kg) & NSF (unit) & NFB (unit) \\
\hline Block & 2 & $3.50284^{\text {ns }}$ & $6.52768^{*}$ & $0.029167^{\mathrm{ns}}$ & $0.316667^{\mathrm{ns}}$ \\
\hline Conductivity & 4 & $436.071^{* *}$ & $242.583^{* *}$ & $0.141667^{*}$ & $1.125000^{*}$ \\
\hline Linear & 1 & $1675.96^{* *}$ & $907.610^{* *}$ & $0.533333^{* *}$ & $4.408333^{*}$ \\
\hline Square & 1 & $15.3005^{*}$ & $9.60971^{\text {ns }}$ & $0.000000^{\mathrm{ns}}$ & $0.053571^{\mathrm{ns}}$ \\
\hline Residue & 8 & 1.14478 & 11.0558 & 0.029167 & 0.306250 \\
\hline C.V. (\%) & & 1.53 & 6.78 & 6.74 & 19.53 \\
\hline
\end{tabular}

S.V. - sources of variation, C.V. - Coefficient of variation; D.F. - Degrees of freedom; ${ }^{* *},{ }^{*}$ - Significant at 1 and $5 \%$ level of significance respectively, ns - non-significant by F test at $5 \%$ level of significance. 

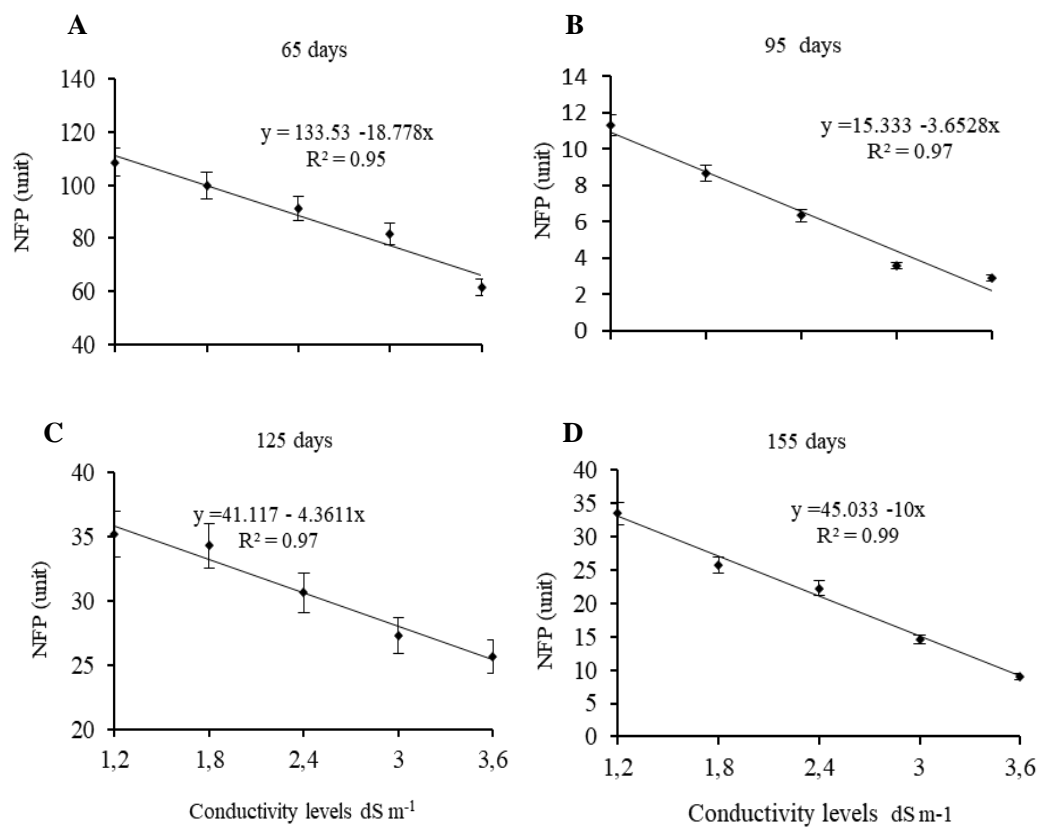

Fig 3. Jatropha curcas number of fruits per plant (NBP) at 65 (A), 95 (B), 125 (C), and 155 (D) days after the beginning of application of different electrical conductivity levels in the irrigation water.

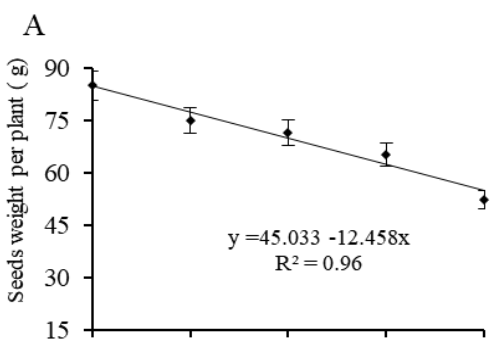

B
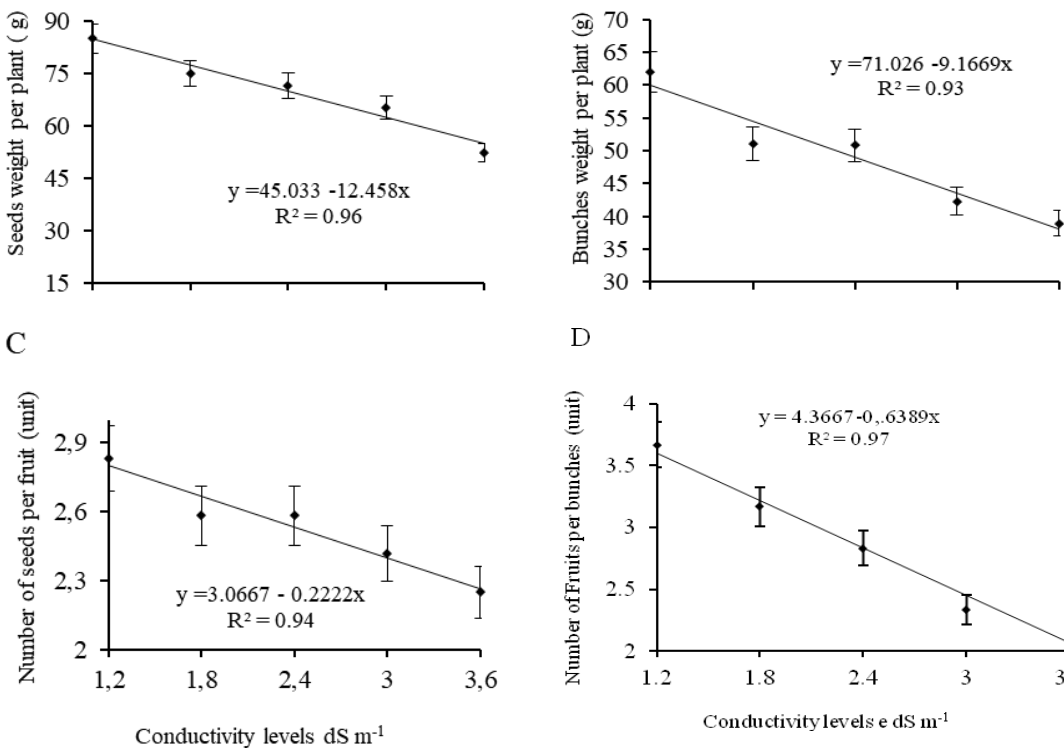

$\mathrm{D}$

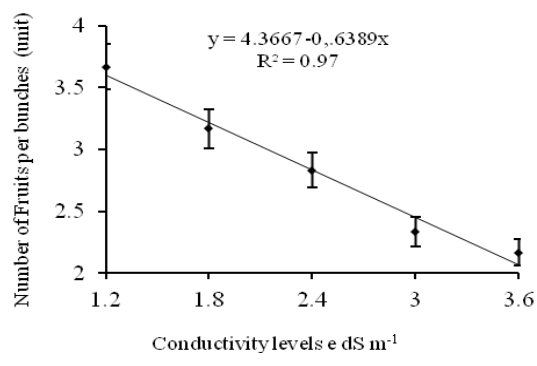

Fig 4. Jatropha curcas seeds weight per plant (SWP) (A), bark weight per plant (BWP) (B), number of seeds per plant (NSP) (C), and number of fruits per bunches (NFB) (D) under different of electrical conductivity levels of the irrigation water.

reduction in seed weight was $38 \%$ between the lowest and highest level of water salinity. Bark weight was adjusted to the linear model $\left(R^{2}=0.93^{*}\right)$. There was decrease up to maximum salinity level of $3.6 \mathrm{dS} \mathrm{m}^{-1}$. The maximum bark weight $(61.91 \mathrm{~g})$ was achieved at the lowest salinity level and showed a decrease of $10.1 \mathrm{~g}$ for each ECW additional unit value, which represented a reduction of $37.25 \%$ (Fig 4 B). Similarly, the number of seeds per fruit (NSF) it was also adjusted to a linear model $\left(R^{2}=0.94 *\right)$ because, when the $\mathrm{ECW}$ of the irrigation water was increased for each $0.6 \mathrm{dS} \mathrm{m}$ ${ }^{1}$, it reduced by $0.13 \mathrm{NSF}$ (Fig $4 \mathrm{C}$ ). The number of fruits per bunches (NFC) was adjusted to a linear regression model $\left(R^{2}\right.$ $=0.97^{*}$ ) with highest 3.6 fruits per plant with the salinity level and it decreased by $37.25 \%$ up to the highest level of $3.6 \mathrm{dS} \mathrm{m}^{-1}$ (Fig $4 \mathrm{D}$ ).

\section{Discussion}

J. curcas gas exchanges were affected significantly when water salinity was increased (Sapeta et al., 2013; Silva et al., 2015; Santana et al., 2017). However, reductions in gas exchange are often observed in response to salinity in species such as castor bean (Lima et al., 2017), sunflower (Sousa Júnior et al., 2017), and cotton plant (Soares et al., 2018). Similar behavior among photosynthetic rate, stomatal conductance, and transpiration suggests that the 
photosynthetic limitation, induced by the increase of the salinity, was provided mainly by stomatal opening limitation. Santos et al. (2013) grew J. curcas in low water soil availability and found a positive correlation between stomatal conductance and transpiration, showing that transpiration is strongly influenced by stomatal regulation. Santana et al. (2017) identified that both photosynthesis and transpiration has positive relation with stomatal conductance in J. curcas under water deficit and flooding. They reported that this is due to reductions of physiological characteristics that heavily influenced by the decreased stomatal opening. Similar results occured in plants under salt stress (Lima et al., 2017).

Stomatal closure, as seen at this current research, is a typical plant answer to salt stress (Cruz et al., 2017; Melo et al., 2017b; Soares et al., 2018). Under salt stress, stomatal closure is attributed to the lower leaf water potential that is promoted by the increase of salinity, leading to turgor loss of the cell (Santana et al., 2017). This answer is probably associated to osmotic stress due to the accumulation of sodium in the leaves (Silva et al., 2011). Thus, the permeability to $\mathrm{CO}_{2}$ flow is reduced (Melo et al., 2017a; Lima et al., 2017). Soares et al. (2018) reported that cotton plants, irrigated with different levels of salinity water, presented reductions in stomatal conductance and transpiration, whose behavior compromised the rate of $\mathrm{CO}_{2}$ assimilation. In addition, J. curcas plants appear to have undergone nonstomatic limitations with the addition of saline water. When saline stress becomes sufficiently severe to cause large reductions in plant gas exchange, biochemical changes also occur and could indicate photosynthetic limitations regardless of stomatal conductance (Silva et al., 2011; Sapeta et al., 2013; Cruz et al., 2017). In this study, saline stress was associated to the decrease of carboxylation efficiency. Similar results were reported by Santana et al. (2017) on J. curcas grown under water stress and flooding. Reduction in the carboxylation efficiency was also observed in pepper plants which presented reduced carboxylation with the increase of the saline water (Melo et al., 2017a). Probably this effect takes place because instantaneous carboxylation efficiency is related to $\mathrm{CO}_{2}$ assimilation rate that is affected by saline water.

Decrease of the maximum efficiency of photosystem II (PSII) due to the raise in water salinity, as observed by the reduction of $\mathrm{Fv} / \mathrm{Fm}$, suggests that $J$. curcas plants had the photosynthetic apparatus affected by the increase of water salinity. Similar results were observed for sunflower (Azevedo Neto et al., 2011) and passionfruit plants (Freire et al., 2014). The rise in salt concentration in the water affects the photochemical apparatus of plants by the accumulation of toxic salts in leaf tissues which, promotes the rupture of membranes and cellular organelles, such as chloroplasts (Silva et al., 2011; Melo et al., 2017a). In J. curcas, Fv/Fm reached 0.73 in the semi-humid and 0.51 in the semi-arid regions during the dry season and under field conditions, (Santos et al., 2013). They also indicated damage to the photochemical apparatus of plants. In addition, these researchers identified correlation of $\mathrm{Fv} / \mathrm{Fm}$ with the rate of photosynthesis. They inferred that the gas exchange reduction due to saline stress is followed by decreasing of the PSII photochemical activity, along with the increase in the photoinhibition. Currently, saline stress presents a photoinhibitory effect on plants which is characterized by the significant decrease in maximum efficiency of photosystem II (PSII) (Azevedo Neto et al., 2011; Augustus et al., 2002). It is associated with a decrease in photosynthetic capacity when a higher $\mathrm{NaCl}$ concentration is present in the water (Santos et al., 2013; Freire et al., 2014).

Reductions in gas exchange and photochemical efficiency of the PSII is associated with increase in water salinity, reflected on the yield of $J$. curcas as well as in the decline of all measured production components. Based on this study, the number of bunches, fruits and seeds and fruits weight were reduced by the salinity. These changes may have occurred as a consequence of the limitation of $\mathrm{CO}_{2}$ assimilation which is affected by the salt damage to the photosystem II. These results are congruent with Soares et al. (2018) who observed weight reduction on unprocessed cotton fiber when cotton plants were irrigated with high salt concentration water. Weight reductions were more significant in plants exposed to salinity from flowering and it reached close to $60 \%$. According to Santos et al. (2013), adverse conditions affect not just the development of $J$. curcas, but also production mainly by reducing the number of plants and fruits development, which may vary by the type and intensity of stress (Santana et al., 2017; Soares et al., 2018).

Saline water applied to J. curcas changed the yield of fruits, increased the number of days to harvest, decreased the number of fruits and fruits and seeds weight, negatively and directly influencing plants production.

\section{Materials and Methods}

\section{Experimental area}

The experiment was carried out at Center of Agrarian and Environmental Sciences, Campus II of the Paraíba State University (UEPB), Lagoa Seca, Paraíba, Brazil (latitude 70 09' S; longitude 350 52' W Greenwich, and elevation $634 \mathrm{~m}$ ).

Climate data (relative humidity, minimum, average and maximum temperatures, wind speed, sun radiation, rainfall, and evapotranspiration) were obtained from Climatological Station of Paraíba at the State Agricultural Research Company (EMEPA) located near the experimental area.

\section{Plant materials}

This research was conducted in the third crop cycle after plants pruning. Plants were irrigated with filtered water by disc filters to remove organic matter. Afterwards, the water irrigation was artificially salinized and stored at reservoir with 3,000L capacity.

Experimental area presented $15 \%$ of slope, deep soil (Classified as Entisol Psaments), sandy texture, good drainage, moderately fertile and presented the following composition: $\mathrm{pH}$ in $\mathrm{H}_{2} \mathrm{O}$ 5.1, $\mathrm{P} \mathrm{0.3},\left(\mathrm{mg} \mathrm{dm}^{-3}\right), \mathrm{K}^{+} 0.5, \mathrm{Na}^{+}$0.4, $\mathrm{Ca}^{+2}$ 3.7, $\mathrm{Mg}^{+2}$ 6.5, $\mathrm{Al}^{+3} 5.0, \mathrm{H}^{++} \mathrm{Al}^{+} 3$ 28.9, $\mathrm{T}$ 40.0, (cmolc dm${ }^{-3}$ ), BS $28.0(\%)$, OM $3.6, \mathrm{~N} 0.0\left(\mathrm{~g} \mathrm{~kg}^{-1}\right)$, sand 81.44 , silt 13.79 , clay 4.77 (\%), bulk density 1.52 , particle density $2.85\left(\mathrm{~g} \mathrm{~cm}^{-3}\right)$, porosity $46.67(\%)$, natural humidity $0.30(\%)$, available water 1.43.

\section{Salt treatments, conduction of study and experimental design}

Treatments were arranged in randomized blocks with five electric conductivity levels of irrigation water: $N_{1}=1.20 ; N_{2}=$ 
1.80; $\mathrm{N}_{3}=2.40 ; \mathrm{N}_{4}=3.00$, and $\mathrm{N}_{5}=3.60 \mathrm{dS} \mathrm{m}^{-1}$, at $25 \stackrel{\circ}{\circ}$, with three replications, 15 experimental plots composed of 18 plants (4 plants used for analysis). Electrical conductivity levels in the water (ECW) were obtained by dissolution of sodium chloride $(\mathrm{NaCl})$, magnesium chloride $\left(\mathrm{MgCl}_{2}\right)$, and potassium chloride $(\mathrm{KCl})$ until reaching the desired $\mathrm{ECW}$, measured through a conductivity meter. The ECW of the dam water was always assessed before each irrigation frequency and before the salinization of reservoir water $(3,000 \mathrm{~L})$.

The first irrigation was intended to raise soil water to the field capacity (FC). The amount of irrigated water subsequently applied varied according to the reference evapotranspiration (ETo) and the climatological water balance. These parameters were calculated based on crop coefficient (Kc) equal to 1.0 (Kc = ETc/ETo) (8 months plants and after being pruned) and crop evapotranspiration (ETC) equal to ETo. Irrigation was applied with 4 and 3 days irrigation frequency, respectively. At 70 days after the beginning of the application of the saline water, the following physiological assessments were made: photochemical efficiency of photosystem II measured by a Fluorometer PEA II - Plant Efficiency Analyzer (Hansatech Instruments (o., UK) and gas exchange through stomatal conductance ' $g s^{\prime}\left(\mathrm{mol} \mathrm{m}^{-2} \mathrm{~s}^{-1}\right)$, transpiration ' $E$ ' $\left(\mathrm{mmol} \mathrm{m} \mathrm{m}^{-2} \mathrm{~s}\right.$ ' $\left.{ }^{1}\right), \mathrm{CO}_{2}$ internal concentration $(\mathrm{Ci})\left(\mu \mathrm{mol} \mathrm{mol}{ }^{-1}\right)$, and leaf net

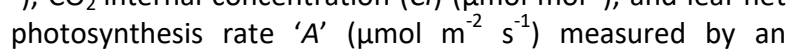
infrared gas analyzer (IRGA) model LCPro+ (ADC, UK). Measurements were made on the 4th fully expanded leaf from one of the four experimental plot plants, at three replicates. These leaves were free of pests, diseases or any other abnormal signs or symptoms. Carboxylation efficiency was calculated by relation between photosynthesis rate $(A)$ and $\mathrm{CO}_{2}$ internal concentration $(\mathrm{C}$ i) relation. J. curcas production was measured at four plants on each experimental plot, based on the following variables: number of bunches per plant (NBP), number of fruits per plant (NFP), number of fruits per bunch (NFB), weight of shells per plant (WSP) (kg), and weight of seeds per plant (WSEP) (Kg).

\section{Statistical analysis}

The data were submitted to analysis of variance up to $5 \%$ probability. In case of significance, data were submitted to regressions by SAEG and Table Curve 2D software.

\section{Conclusion}

Continuous application of saline water after $J$. curcas pruning drastictly reduced up to $31.1 \%$ in gas exchange $(A, g s, E, C i$, and $A / C i)$. Photochemical efficiency of photosystem II was restricted by salinity at $2.4 \mathrm{dS} \mathrm{m}^{-1}$ level. Increasing electrical conductivity in irrigation water at levels above $1.20 \mathrm{dS} \mathrm{m}^{-1}$ significantly reduced $J$. curcas production components by up to $77.3 \%$. Irrigation with saline water up to the level $1.20 \mathrm{dS}$ $\mathrm{m}^{-1}$ did not damage gas exchange and fruit production of Jatropha curcas crop.

\section{Acknowledgment}

The authors would like to thank the Paraíba State University (UEPB), Federal University of Campina Grande (UFCG), Brazilian Agricultural Research Corporation (Embrapa Algodão), National Council for Scientific and Technological
Development (CNPq), and the Coordination for the Improvement of Higher Personnel Education (CAPES).

\section{References}

Augustus GDPS, Jayabala NM, Seilerb GJ (2002) Evaluation and bio induction of energy components of Jatropha curcas. Biomass and Bioenergy. 23:161-164.

Achten WMJ, Verchot L, Franken YJ, Mathijs E, Singh VP, Aerts R, Muys B (2008) Jatropha bio-diesel production and use. Biomas and Bioenergy. 32:1063-1084.

Azevedo Neto AD, Pereira PPA, Costa DP, Santos ACC (2011) Fluorescência da clorofila como uma ferramenta possível para seleção de tolerância à salinidade em girassol. Rev Ciên Agron. 42: 893-897.

Brito MEB, Sá FVS, Soares Filho WS, Silva LA, Fernandes PD (2016) Gas exchange and fluorescence of citrus rootstocks varieties under saline stress. Rev Bra Frutic. 38: 1-8.

Cruz JL, Coelho Filho MA, Coelho EF, Santos AA (2017) Salinity reduces carbon assimilation and the harvest index of cassava plants (Manihot esculenta Crantz). Acta Sci Agron. 39: 545-555.

Freire JLO, Dias TJ, Cavalcante LF, Fernandes PD, Lima Neto AJ (2014) Rendimento quântico e trocas gasosas em maracujazeiro amarelo sob salinidade hídrica, biofertilização e cobertura morta. Rev Ciên Agron. 45: 8291.

Lima GS, Gheyi HR, Nobre R G, Soares LAA, Fernandes PD, Furtado, GF (2017) Trocas gasosas, pigmentos cloroplastídicos e dano celular na mamoneira sob diferentes composições catiônica da água. Irriga. 22: 757774.

Melo HFD, Souza ERD, Duarte HH, Cunha JC, Santos HR (2017a) Gas exchange and photosynthetic pigments in bell pepper irrigated with saline water. Rev Bras Eng Agr Amb. 21: 38-43.

Melo HF, Souza ER, Cunha JC (2017b) Fluorescence of chlorophyll a and photosynthetic pigments in Atriplex nummularia under abiotic stresses. Rev Bras Eng Agr Amb. 21: 232-237, 2017.

MUNNS R (2002) Comparative physiology of salt and water stress. Plant Cell Environ. 25: 659-662.

Pivetta LG, Pivetta LA, Castoldi G, Freiberger MB, Zanotto MD, Villas Boas RL (2016) Germination and initial growth of crambe (Crambe abyssinica Hochst.) under saline conditions. Aust J Crop Sci. 11: 1614-1617.

Santana TA, Silva LD, Oliveira PS, Benjamin CS, Ramos EP, Souza Júnior JO, Gomes FP (2017) Leaf gas exchange and biomass partitioning in Jatropha curcas L. young plants subjected to flooding and drought stresses. Aust J Crop Sci. 11: 792-798.

Santos CM, Verissimo V, Wanderley Filho HCL, Ferreira VM, Cavalcante PGS, Rolin EV, Endres L (2013) Seasonal variations of photosynthesis, gas exchange, quantum efficiency of photosystem II and biochemical responses of Jatropha curcas L. grown in semi-humid and semi-arid areas subject to water stress. Ind Crop Prod. 4: 203-213.

Sapeta H, Costa JM, Lourenço T, Maroco J, Linde PV, Oliveira MM (2013) Drought stress response in Jatropha curcas: Growth and physiology. Environ Exp Bot. 85: 76-84.

Silva EN, Ribeiro RV, Ferreira-Silva, SL, Viégas RA, Silveira JAG (2011) Salt stress induced damages on the photosynthesis of physic nut young plants. Sci Agri. 68: 62-68. 
Silva EN, Silveira JA, Ribeiro RV, Vieira AS (2015) Photoprotective function of energy dissipation by thermal processes and photorespiratory mechanisms in Jatropha curcas plants during different intensities of drought and after recovery. Environ Exp Bot. 110: 36-45.

Soares LAA, Fernandes PD, Lima GS, Suassuna JF, Pereira RF (2018) Gas exchanges and production of colored cotton irrigated with saline water at different phenological stages. Rev Ciên Agron. 49: 239-248.

Sousa Júnior JR, Lima GS, Gheyi HR, Lima VLA, Santos JB, Sousa JRM, Furtado GF (2017) Gas exchange and production of sunflower (Helianthus annuus L.) irrigated with water of different salinity, cationic nature and nitrogen doses. Aust J Crop Sci. 11: 300-307. 